\title{
Influence of Sulphur, Zinc and Organic Inorganic Assorted Customized Fertilizer on Yield and Quality of Cotton under Rainfed Vertisols
}

\author{
Bhagchand Bairwa $^{1 *}$, R. N. Katkar ${ }^{1}$, Vrushali Bhende ${ }^{1}$, \\ Shrutika Gawande ${ }^{1}$ and Subhradip Bhattacharjee ${ }^{2}$ \\ ${ }^{1}$ Department of Soil Science and Agricultural Chemistry, ${ }^{2}$ Department of Agronomy, \\ Dr.Panjabrao Deshmukh Krishi Vidyapeeth, Akola, Maharashtra-444104, India \\ *Corresponding author
}

\section{A B S T R A C T}

\begin{tabular}{|l|}
\hline Ke y w or d s \\
Cotton, Customized \\
fertilizer, Sulphur, \\
Zinc, FYM
\end{tabular}

\section{Introduction}

When it comes to the fibre crop; cotton takes the first position. It is also the most prominent cash crop of India (Mandal et al., 2005). India ranks first in the world having an area of 105 lakh ha with the cotton production of 351 lakh bales and productivity of $568 \mathrm{~kg}$ lint per ha. Maharashtra is the leading cotton-growing state in India having 38.06 lakh ha area under cotton cultivation which is one-third of countries area under cotton cultivation with the production of 89 lakh bales. The productivity of cotton in Maharashtra is 398 kg lint per ha (Anonymous, 2016). An
Cotton, the major fibre crop of India grown mainly under the rainfed condition often faces multi-nutritional deficiencies. This experiment was conducted during the Kharif season of $2016-17$ on to find out the best performing nutrient combination for rainfed cotton in which sulphur, zinc and FYM based nutrient management regime, as well as customized fertilizer, were evaluated. The result indicated that gradually adding sulphur and zinc along with compulsory nitrogen, phosphorus and potassic fertilizer improves yield and quality attributes, however, significantly higher yield attributes, yield and quality has been observed when farmyard manure at a rate of five tonnes per hectare has been used along with standard recommended dose of fertilizers. important cotton-growing zone in Maharashtra is Vidarbha. However; being a rainfed cotton growing zone; the area often faces problem due to erratic rainfall; imbalanced fertilizer use and low adoption of improved techniques while ultimately results deteriorating soil health thus limiting yield potential (Blaise et al., 2005a).

In case of imbalanced fertilizer application; the end-result is often multiple nutrient deficiencies owing to the changing soil chemical properties. Sulphur is one such element which often found to be deficient in the soil. On average, 32.9 per cent sulphur 
deficiency has been noticed in Indian soils (Shukla et al., 2016). Sulphur deficiency in Maharashtra recorded to the extent of 27.48 per cent while in the Vidarbha region, it is 25.76 per cent (Katkar et al., 2017). Sulphur fertilization of crops needs to be an integral component of balanced nutrition for producing optimum yield and quality of crops. Crops like cotton, which have high protein and oil in seed, need more substantial quantities of sulphur. For typical yields, the crops with high sulphur requirements need 20 to $45 \mathrm{~kg} \mathrm{~S} \mathrm{ha}^{-1}$ (Singh and Joshi, 2000).

Zinc is another essential micronutrient which is highly deficit in Indian soil. Survey of Indian soils revealed that about 39.9 per cent of 2.52 lakh soil samples analyzed were found deficient in available $\mathrm{Zn}$ distributed over 20 states (Shukla et al., 2016). Zinc deficiency is widespread in all agro-ecological zones (AEZ). Zinc deficiency in Maharashtra has been reported to be 37.8 per cent, and in Vidarbha, 49 per cent (Katkar et al., 2017). Without the regular supply of zinc to the plants; the ill effect becomes more prominent over time. Zinc directly influences yield and quality of crops because of functions such as its activity in biological membrane stability, enzyme activation ability and auxin synthesis (Marschner, 1997).

There are two general methods to correct the sulphur and zinc deficiency. The first method is to use customized fertilizers. Customized fertilizers are multi-nutrient carriers facilitating the application of the complete range of plant nutrients in the right proportion to suit the specific requirements of a crop during its stages of growth. Soil fertility status, climate, and cropping pattern in a region pave the way for the development of customized fertilizer formulations. It optimizes the nutrient use for quality produce, high farm productivity and profitability.
The other method is to the application of organic manure or supplementation of organic manure with inorganic chemical fertilizer. Earlier researches indicated that a more sustainable method of increasing yield potential in rainfed vertisols is the integrated use of both organic and inorganic sources of nutrients (Rajpoot et al., 2009). Organic source of nutrition such as FYM has the potential to store moisture for a longer period as well as releasing nutrients in a steady manner (Patra et al., 2000).

Considering all these factors, we had experimented to evaluate the performance of cotton based on yield and quality under these different nutrient delivery approaches.

\section{Materials and Methods}

\section{Experimental site}

This experiment was carried out during the Kharif (rainy) season of 2016-17 at Research Farm, All India Co-ordinated Research Project on Micro and Secondary Nutrients and Pollutant Elements in Soils and Plants, Department of Soil Science and Agricultural Chemistry, Dr.Panjabrao Deshmukh Krishi Vidyapeeth, Akola, India. The experimental plot is geographically located at the subtropical region between $22.42^{\circ} \mathrm{N}$ latitude, $77.02^{\circ} \mathrm{E}$ longitude, and at an altitude of $307.42 \mathrm{~m}$ above mean sea level. The climatic condition is the sub-tropical type with hot summer, humid monsoon and mild winter. The mean weather data has been summed up on table 1. During the Kharif season of 201617, the total rainfall received (25th MW 2016 to 5th MW 2017) at Akola centre was 823.7 $\mathrm{mm}$ in 43 rainy days as against average rainfall of $711.1 \mathrm{~mm}$ in 38.4 rainy days (1971-2010).

The soil of the experiment site was deep black swell shrink, montmorillonitic mineralogy 
with clay texture and classified under Vertisols (Deshpande et al., 2014). The initial soil properties at the start of the experiment were slightly alkaline (8.15), non - saline (0.37 dS m ${ }^{-1}$ ) (Jackson 1973), moderately calcareous $(6.25 \%)$ and moderately high in organic carbon (5.73 $\mathrm{g} \mathrm{kg}^{-1}$ ) (Keeney and Nelson, 1982).

The available nitrogen was low $(188.15 \mathrm{~kg}$ ha $\left.{ }^{1}\right)$ (Subbaiah, 1956), medium in available phosphorus (16.74 $\mathrm{kg} \mathrm{ha}^{-1}$ ) (Olsen et al., 1954) and high in available potassium (354.3 $\mathrm{kg} \mathrm{ha}{ }^{-1}$ ) (Hanway and Heidel 1952) while marginal in available sulphur (10.37 $\left.\mathrm{mg} \mathrm{ka}^{-1}\right)$ (Chesnin and Yien, 1951). The experimental soil was deficient in DTPA - zinc $(0.57 \mathrm{mg}$ $\mathrm{kg}^{-1}$ ) and sufficient in DTPA - Fe, Mn and $\mathrm{Cu}$ (Lindsay and Norvell, 1978). All physiochemical properties of the experimental site before the commencement of the experiment has been presented on table 2 .

\section{Experimental design and treatment compositions}

The experiment was laid out in Randomized Complete Block Design (RCBD) with eleven treatments which were replicated thrice. The net plot size was $16.2 \mathrm{~m}^{2}$. The treatments were: $\mathrm{T}_{1}$ : Absolute control (No NPK), $\mathrm{T}_{2}$ : Recommended dose of NPK, $\mathrm{T}_{3}$ : Recommended dose of NPKS, T 4 : Recommended dose of NPKS Zn, T 5 : Recommended dose of NPK + FYM, $T_{6}$ : Recommended dose through NPS-1 (compensate $\mathrm{N}$ and $\mathrm{K}$ through conventional sources, $\mathrm{T}_{7}$ : Recommended dose through NPS-2 (compensate $\mathrm{N}$ and $\mathrm{K}$ through conventional sources), $\mathrm{T}_{8}$ : Recommended dose through NPS Zn (compensate $\mathrm{N}$ and $\mathrm{K}$ through conventional sources), $\mathrm{T}_{9}$ : Recommended dose of NPK + Sulphur equivalent to NPS-1 supplied in $\mathrm{T}_{6}, \mathrm{~T}_{10}$ : Recommended dose of NPK + Sulphur equivalent to NPS- 2 supplied in $T_{7}$ and $T_{11}$ : Recommended dose of NPK + Sulphur and
$\mathrm{Zn}$ equivalent to NPS $\mathrm{Zn}$ supplied in $\mathrm{T}_{8}$. The NPS-1 had nitrogen: phosphorus: sulphur at a ratio of 19:38:07 while the NPS-2 contained 12:46:07. In the case of NPS Zn, it had nitrogen: phosphorus: sulphur: zinc in a ratio of 12:45:05:01.

The half dose of nitrogen as basal, a full dose of phosphorus, potassium, sulphur and zinc was applied at the time of sowing while the remaining half of the nitrogen was applied thirty days after sowing by urea. Nitrogen, phosphorus and potassium were applied through urea, diammonium phosphate and muriate of potash.

The sulphur was applied through bentonite sulphur $(90 \% \quad$ S) while zinc sulphate heptahydrate $(21 \% \mathrm{Zn})$ was used as zinc source. The compost was analysed in advance for chemical composition which revealed it had $\mathrm{C}$ : $\mathrm{N}$ ratio of $16.14: 1,0.61 \% \mathrm{~N}, 0.35 \% \mathrm{P}$, $0.42 \% \mathrm{~K}, 0.07 \mathrm{mg} \mathrm{kg}^{-1} \mathrm{~S}, 64.99 \mathrm{mg} \mathrm{kg}^{-1} \mathrm{Zn}$, $94.00 \mathrm{mg} \mathrm{kg}^{-1} \mathrm{Cu}, 2109 \mathrm{mg} \mathrm{kg}^{-1} \mathrm{Fe}$ and 439.4 $\mathrm{mg} \mathrm{kg}^{-1} \mathrm{Mn}$.

\section{Sowing and cultural operations}

The experimental land was ploughed, harrowed, made free of grasses before the layout. Initial plot-wise surface soil samples were collected randomly from 0-20 cm depth. The collected samples were mixed thoroughly, and finally, plot-wise samples were retained for analysis.

The Bt. Cotton variety Ajeet 199 BG-II was sown using the dibbling method and two seeds were placed in each hole although one plant has been removed on a later stage to ensure even plant population. The spacing has been kept at 90 X $45 \mathrm{~cm}$. The experimental site was kept weed-free by periodic hand weeding. Two sprays of Confidor 17.8 SL and Monocrotophous 3G on the crop leaves was undertaken to control the aphids, jassids and whitefly on cotton. 


\section{Recording of biometric observation and harvesting}

Five plants were randomly selected from each plot and tagged for biometric observations. The pickings of seed cotton were done from each plot, four pickings were carried out, and total yield from each treatment in all the replications was recorded, and per hectare, seed cotton yield was determined.

The plant samples above-ground part were collected at second picking and kept in paper bags and air-dried in the shade. The samples were eventually kept in a hot air oven at $64^{\circ} \mathrm{C}$ till the constant weight has been achieved. After complete drying the; dry matter of stem, leaves and fruit parts were.

\section{Oil content and fibre quality assessment}

The Soxhlet apparatus has neem used to estimate the oil content in cottonseed. The standard procedures have been followed in case of fibre quality assessment. Digital fibrograph, stelometer, and micronaire instrument have been used to measure the span length, strength (tenacity) and fineness of the fibre.

\section{Statistical analysis and interpretation of data}

The observed, recorded, and data were analyzed in randomized complete block design using the $\mathrm{R}$ statistical program (deploying CRAN- Agricolae library) following the procedure of Gomez and Gomez (1984).

The significance of treatments was tested using the " $F$ " test. The difference of treatment means was compared and alphabetically ranked using Duncan Multiple Range Test (DMRT) at 5\% level of significance.

\section{Results and Discussion}

\section{Effect of nutrient sources on yield attributes}

\section{Number of bolls per plant}

Cotton yield and yield components are highly dependent on basic fertilizer levels and appropriate plant population (Ali et al., 2007). Among yield components, Bolls plant ${ }^{-1}$ is one of the critical factors which directly influences the yield (Boquet et al., 1994). The treatments of our experiment had a distinctive effect on bolls plant ${ }^{-1}$ (Table 3). The highest number of bolls plant $^{-1}$ has been recorded with the application of RDN along with FYM $\left(\mathrm{T}_{5}\right)$ which had $52.69 \%$ more bolls than absolute control $\left(\mathrm{T}_{1}\right)$; however, it was found to be at par with $\mathrm{T}_{4}(\mathrm{NPKS} \mathrm{Zn}$ through conventional sources) and $\mathrm{T}_{8}$ (RDN grade III + compensated $\mathrm{N}$ and $\mathrm{K}$ through conventional sources).

The treatment wise breakdown indicated that addition of NPK resulted in $30.63 \%$ increase in the number of bolls while further addition of $\mathrm{S}$ caused $8.01 \%$ and $\mathrm{Zn}$ caused $12.83 \%$ increment. The FYM in $\mathrm{T}_{5}$ which seemingly supplied other micronutrients had $2.22 \%$ more Bolls plant ${ }^{-1}$ as compared to $\mathrm{T}_{4}$ which had only N, P, K, S and Zn. Blaise et al., (2005b) earlier reported that significantly higher bolls plant ${ }^{-1}$ has been observed in the case of collective application of fertilizer (NPK) and FYM, especially in the first year of application. In addition to supplying micronutrients; FYM also helps to store soil moisture which becomes crucial, especially in case of rainfed condition (Venugopalan and Pundarikakshudu, 1999; Gokhale et al., 2011). Increment in number of bolls due to the sulphur application is may be due to sulphur being an essential constituent of enzymatic activity, responsible for nitrogen metabolism including nitrate and nitrite 
reductase (Swamy et al., 2005). The increment due to zinc application are in agreement with those of Potarzycki and Grzebisz (2009) and Abid et al., (2013) who argued that supplementation of zinc on soil results increased zinc content on plant leaf which enhances the higher assimilation of photosynthates from source to sink resulting in better yield. Another vital aspect of zinc application is that it improves the activity of tryptophan synthesis, which is responsible for the growth control compound indole-3- acetic acid; the compound which helps to retain a higher number of bolls per plant (Follett et al., 1981 and Qingfang, 1996).

Table.1 Meteorological observations during study period (2016-2017)

\begin{tabular}{|c|c|c|c|c|c|c|}
\hline \multirow[t]{2}{*}{ Month } & \multicolumn{2}{|c|}{ Temperature $\left({ }^{\circ} \mathrm{C}\right)$} & \multicolumn{2}{|c|}{ Relative humidity (\%) } & \multirow{2}{*}{$\begin{array}{l}\text { Total } \\
\text { rainfall } \\
(\mathbf{m m})\end{array}$} & \multirow{2}{*}{$\begin{array}{c}\text { Total } \\
\text { evaporation } \\
(\mathbf{m m})\end{array}$} \\
\hline & $\begin{array}{c}\text { Mean } \\
\text { Maximum }\end{array}$ & $\begin{array}{c}\text { Mean } \\
\text { Minimum }\end{array}$ & $\begin{array}{c}\text { Mean } \\
\text { Maximum }\end{array}$ & $\begin{array}{c}\text { Mean } \\
\text { Minimum }\end{array}$ & & \\
\hline 20-30 June & 35.4 & 26.1 & 72.66 & 44.33 & 139.7 & 28.1 \\
\hline 1- 31 July & 30.58 & 24.3 & 87.2 & 69.6 & 376.1 & 20.7 \\
\hline 1-31 August & 30.54 & 23.84 & 84.25 & 62.5 & 30.7 & 17.5 \\
\hline 1- 30 September & 31.34 & 23.4 & 88.4 & 61.8 & 123.2 & 18.2 \\
\hline 1- 31 October & 31.1 & 20.2 & 87.46 & 53.63 & 90.5 & 11.7 \\
\hline 1-30 November & 30.95 & 11.77 & 77.3 & 52.6 & 00 & 15.5 \\
\hline 1-31 December & 30.18 & 9.86 & 76.7 & 51.4 & 00 & 16.0 \\
\hline 1-31 January & 28.5 & 9.53 & 72.4 & 50.8 & 00 & 18.7 \\
\hline 1-28 February & 30.2 & 10.7 & 71.6 & 46.7 & 00 & 17.4 \\
\hline
\end{tabular}

Table.2 Physiochemical properties of the soil prior to the experiment

\begin{tabular}{|c|l|c|}
\hline Sr. No. & \multicolumn{1}{|c|}{ Particulars } & Value \\
\hline $\mathbf{A}$ & Soil properties & 8.15 \\
\hline $\mathbf{1}$ & $\mathrm{pH}(1: 2.5)$ & 0.37 \\
\hline $\mathbf{2}$ & EC $\left.(\mathrm{dS} \mathrm{m})^{-1}\right)$ & 5.73 \\
\hline $\mathbf{3}$ & Organic carbon $\left(\mathrm{g} \mathrm{kg}^{-1}\right)$ & 6.25 \\
\hline $\mathbf{4}$ & Calcium carbonate $\left(\mathrm{CaCO}_{3}\right)(\%)$ & \\
\hline $\mathbf{B .}$ & Fertility analysis & 188.15 \\
\hline $\mathbf{1}$ & Available $\mathrm{N}\left(\mathrm{kg} \mathrm{ha}^{-1}\right)$ & 16.74 \\
\hline $\mathbf{2}$ & Available $\mathrm{P}_{2} \mathrm{O}_{5}\left(\mathrm{~kg} \mathrm{ha}^{-1}\right)$ & 354.3 \\
\hline $\mathbf{3}$ & Available $\mathrm{K}_{2} \mathrm{O}\left(\mathrm{kg} \mathrm{ha}^{-1}\right)$ & 10.37 \\
\hline $\mathbf{4}$ & Available $\mathrm{S}\left(\mathrm{mg} \mathrm{kg}^{-1}\right)$ & 0.57 \\
\hline $\mathbf{5}$ & DTPA extractable $\mathrm{Zn}\left(\mathrm{mg} \mathrm{kg}^{-1}\right)$ & 12.7 \\
\hline $\mathbf{6}$ & DTPA extractable $\mathrm{Mn}\left(\mathrm{mg} \mathrm{kg}^{-1}\right)$ & 4.93 \\
\hline $\mathbf{7}$ & DTPA extractable Fe $\left(\mathrm{mg} \mathrm{kg}^{-1}\right)$ & 3.23 \\
\hline $\mathbf{8}$ & DTPA extractable Cu $\left(\mathrm{mg} \mathrm{kg}^{-1}\right)$ & 0.56 \\
\hline $\mathbf{9}$ & Available extractable B $\left(\mathrm{mg} \mathrm{kg}^{-1}\right)$ & \\
\hline
\end{tabular}


Table.3 Effect of different treatments on bolls plant ${ }^{-1}$, boll weight $(\mathrm{g})$, seed cotton yield (q ha $\left.{ }^{-1}\right)$, cotton stalk yield $\left(\mathrm{q} \mathrm{ha}^{-1}\right)$ and oil content $(\%)$

\begin{tabular}{|c|c|c|c|c|c|}
\hline \multirow[t]{2}{*}{ Treatments } & \multirow[t]{2}{*}{ Bolls plant ${ }^{-1}$} & \multirow{2}{*}{$\begin{array}{c}\text { Boll weight } \\
\text { (g) }\end{array}$} & \multicolumn{2}{|c|}{ Yield (q ha $\left.{ }^{-1}\right)$} & \multirow[t]{2}{*}{ Oil\% } \\
\hline & & & Seed Cotton & Cotton stalk & \\
\hline $\mathbf{T}_{1}$ & $17.50 \pm 0.38 f$ & $3.02 \pm 1.6 f$ & $10.44 \pm 0.49 \mathrm{e}$ & $23.52 \pm 0.37 \mathrm{~g}$ & 18.93 \\
\hline $\mathbf{T}_{2}$ & $23.83 \pm 0.42 \mathrm{e}$ & $3.29 \pm 0.71 \mathrm{de}$ & $16.07 \pm 0.37 d$ & $35.38 \pm 0.39 f$ & 19.38 \\
\hline $\mathbf{T}_{3}$ & $25.82 \pm 0.21 \mathrm{de}$ & $3.59 \pm 1.33 b c$ & $18.23 \pm 0.42 b c$ & $37.57 \pm 0.52 \mathrm{de}$ & 19.52 \\
\hline $\mathbf{T}_{4}$ & $29.36 \pm 0.44 \mathrm{ab}$ & $3.72 \pm 0.47 \mathrm{a}$ & $19.88 \pm 0.47 \mathrm{ab}$ & $42.61 \pm 0.49 b$ & 19.72 \\
\hline $\mathbf{T}_{5}$ & $30.02 \pm 0.32 \mathrm{a}$ & $3.81 \pm 0.45 a$ & $21.29 \pm 0.79 a$ & $44.63 \pm 0.61 \mathrm{a}$ & 19.65 \\
\hline $\mathbf{T}_{6}$ & $23.75 \pm 0.28 \mathrm{e}$ & $3.49 \pm 0.52 \mathrm{~cd}$ & $17.58 \pm 0.81 \mathrm{~cd}$ & $38.74 \pm 0.67 \mathrm{~cd}$ & 18.99 \\
\hline $\mathbf{T}_{7}$ & $25.43 \pm 0.43 \mathrm{de}$ & $3.31 \pm 1.23 \mathrm{~d}$ & $16.87 \pm 0.69 \mathrm{~cd}$ & $37.97 \pm 0.42 \mathrm{cde}$ & 19.29 \\
\hline T8 & $28.75 \pm 0.37 \mathrm{ab}$ & $3.62 \pm 0.65 b$ & $19.70 \pm 0.86 \mathrm{ab}$ & $41.91 \pm 0.73 b$ & 19.41 \\
\hline T9 & $25.83 \pm 0.39 \mathrm{~cd}$ & $3.42 \pm 0.71 \mathrm{~cd}$ & $17.34 \pm 0.67 \mathrm{~cd}$ & $37.56 \pm 0.70 \mathrm{de}$ & 19.11 \\
\hline $\mathbf{T}_{10}$ & $26.63 \pm 0.31 \mathrm{~cd}$ & $3.37 \pm 0.67 \mathrm{~cd}$ & $16.60 \pm 0.43 \mathrm{~cd}$ & $36.93 \pm 0.59 e$ & 19.71 \\
\hline $\mathbf{T}_{11}$ & $26.52 \pm 0.43 c$ & $3.51 \pm 0.44 \mathrm{~cd}$ & $17.98 c \pm 0.77 c$ & $39.22 \pm 0.66 c$ & 19.59 \\
\hline
\end{tabular}

(NS: Not Significant. Treatments sharing at least one common alphabet does not differ significantly as per Duncan Multiple Range Test at 5\% level of significance. Treatment effect is not significant in oil \%)

Table.4 Effect of different treatments on fibre quality of cotton

\begin{tabular}{|c|c|c|c|c|c|c|}
\hline Treatments & $\begin{array}{c}\text { UHML } \\
(\mathbf{m m})\end{array}$ & UI (\%) & $\begin{array}{c}\text { MIC } \\
\left(\mu \mathrm{g} \mathrm{in}^{-1}\right)\end{array}$ & $\begin{array}{l}\text { Tenacity } 3.2 \\
\left.\text { mm }^{\left(g_{\text {tex }}\right.}{ }^{-1}\right)\end{array}$ & $\begin{array}{l}\text { EL } \\
(\%)\end{array}$ & GP (\%) \\
\hline $\mathbf{T}_{1}$ & $29.87 \pm 0.8 \mathrm{e}$ & $82.0 \pm 0.53$ & $3.17 \pm 0.32$ & $32.13 \pm 1.31 \mathrm{c}$ & $6.27 \pm 0.21 d$ & $33.27 \pm 0.71 b$ \\
\hline $\mathbf{T}_{2}$ & $30.77 \pm 1.13 b$ & $82.3 \pm 0.71$ & $3.13 \pm 0.30$ & $35.14 \pm 1.60 \mathrm{a}$ & $6.60 \pm 0.34 a$ & $31.93 \pm 0.84 f$ \\
\hline $\mathbf{T}_{3}$ & $30.43 \pm 1.11 \mathrm{c}$ & $82.3 \pm 0.47$ & $3.30 \pm 0.41$ & $32.87 \pm 1.22 b c$ & $6.47 \pm 0.27 \mathrm{abc}$ & $33.07 \pm 0.72 c$ \\
\hline $\mathbf{T}_{4}$ & $30.20 \pm 0.98 d$ & $82.0 \pm 0.53$ & $3.33 \pm 0.43$ & $33.37 \pm 0.97 \mathrm{abc}$ & $6.40 \pm 0.21 \mathrm{bcd}$ & $33.17 \pm 0.59 b$ \\
\hline $\mathbf{T}_{\mathbf{5}}$ & $30.93 \pm 1.07 \mathrm{a}$ & $82.3 \pm 0.21$ & $2.97 \pm 0.41$ & $35.27 \pm 1.15 \mathrm{a}$ & $6.50 \pm 0.29 \mathrm{ab}$ & $32.83 \pm 0.48 d$ \\
\hline $\mathbf{T}_{6}$ & $30.13 \pm 1.2 \mathrm{~d}$ & $82.0 \pm 0.20$ & $3.27 \pm 0.43$ & $32.80 \pm 1.12 b c$ & $6.33 \pm 0.22 \mathrm{~cd}$ & $32.60 \pm 0.43 e$ \\
\hline $\mathbf{T}_{7}$ & $30.07 \pm 1.27 \mathrm{~d}$ & $82.0 \pm 0.49$ & $3.17 \pm 0.22$ & $33.83 \pm 1.37 \mathrm{abc}$ & $6.37 \pm 0.30 \mathrm{bcd}$ & $32.87 \pm 0.41 d$ \\
\hline T8 & $30.47 \pm 1.21 c$ & $82.0 \pm 52$ & $3.23 \pm 0.37$ & $32.97 \pm 1.28 \mathrm{bc}$ & $6.40 \pm 0.18 \mathrm{bcd}$ & $31.97 \pm 0.62 f$ \\
\hline T9 & $30.47 \pm 0.97 c$ & $82.0 \pm 0.66$ & $3.23 \pm 0.42$ & $33.83 \pm 1.22 \mathrm{abc}$ & $6.50 \pm 0.26 \mathrm{ab}$ & $33.33 \pm 0.48 b$ \\
\hline $\mathbf{T}_{10}$ & $30.80 \pm 1.21 \mathrm{ab}$ & $82.3 \pm 0.65$ & $2.97 \pm 0.34$ & $34.67 \pm 1.13 \mathrm{ab}$ & $6.43 \pm 0.19 b c$ & $32.83 \pm 0.52 \mathrm{~d}$ \\
\hline $\mathbf{T}_{11}$ & $30.43 \pm 1.13 c$ & $82.0 \pm 0.53$ & $2.98 \pm 0.21$ & $34.50 \pm 1.25 \mathrm{ab}$ & $6.37 \pm 0.27 \mathrm{bcd}$ & $33.47 \pm 0.47 \mathrm{a}$ \\
\hline
\end{tabular}

(NS: Not Significant. Treatments sharing at least one common alphabet does not differ significantly as per Duncan Multiple Range Test at 5\% level of significance. Treatment effect is not statistically significant in UI and MIC) 
Table.5 Pearson correlation matrix among cotton yield, yield attributes and quality attributes

\begin{tabular}{|c|c|c|c|c|c|c|c|c|}
\hline & $\begin{array}{c}\text { Seed cotton } \\
\text { yield }\end{array}$ & $\begin{array}{c}\text { Stalk } \\
\text { yield }\end{array}$ & $\begin{array}{c}\text { No. bolls } \\
\text { plant }\end{array}$ & $\begin{array}{c}\text { Boll } \\
\text { weight }\end{array}$ & $\begin{array}{c}\text { Oil } \\
\text { content }\end{array}$ & UHML & Tenacity & EL \\
\hline Seed cotton yield & 1 & $0.988^{* *}$ & $0.957^{* *}$ & $0.959^{* *}$ & $0.639^{*}$ & $0.514^{*}$ & $0.391 \#$ & $0.400 \#$ \\
\hline Stalk yield & & 1 & $0.957^{* *}$ & $0.917^{* *}$ & $0.627^{*}$ & $0.0 .496 \#$ & $0.435 \#$ & $0.372 \#$ \\
\hline No. bolls plant & -1 & & 1 & $0.899^{* *}$ & $0.768^{* *}$ & $0.569^{*}$ & $0.470 \#$ & $0.406 \#$ \\
\hline Boll weight & & & 1 & $0.634^{*}$ & $0.440 \#$ & $0.253 \#$ & $0.293 \#$ \\
\hline $\begin{array}{l}\text { Oil content } \\
\text { UHML }\end{array}$ & & & & 1 & $0.615^{*}$ & $0.570^{*}$ & $0.384 \#$ \\
\hline Tenacity & & & & & 1 & $0.819^{* *}$ & $0.797^{* *}$ \\
\hline EL & & & & & & 1 & $0.688^{*}$ \\
\hline
\end{tabular}

\section{Boll weight (g)}

The boll weight (g) was heaviest in $\mathrm{T}_{5}$ and $\mathrm{T}_{4}$, which were $23.13 \%$ and $20.77 \%$ higher than the control $\left(\mathrm{T}_{1}\right)$, respectively (Table 3 ). Among different graded fertilizers, $\mathrm{T}_{8}$ recorded $18.07 \%$ heavier boll than the control. The treatment wise breakdown indicates that addition of NPK causes $8.56 \%$ increase in boll weight over the control. Further addition of S with NPK causes $8.72 \%$ and increment in boll weight over NPK alone. Again, when $\mathrm{Zn}$ is added with NPKS, it caused $3.56 \%$ additional increment. In the case of FYM, it recorded $2.39 \%$ heavier boll than NPKS Zn combination which might be due to the favourable soil condition, better water holding capacity and supply of additional micronutrient.

\section{Seed cotton and cotton stalk yield}

$\mathrm{T}_{5}$ also recorded statistically higher seed cotton yield ( $\mathrm{q} \mathrm{ha}^{-1}$ ) along with $\mathrm{T}_{4}$ and $\mathrm{T}_{8}$, which were $68.38 \%, 62.27 \%$ and $61.45 \%$ higher than the $\mathrm{T}_{1}$ (control) (Table 3 ). In case of cotton stalk yield ( $\mathrm{q} \mathrm{ha}^{-1}$ ); $\mathrm{T}_{5}$ (followed by $\mathrm{T}_{4}$ and $\mathrm{T}_{8}$ ) was absolutely superior over all other treatments and recorded $61.95 \%$ increment in yield over $\mathrm{T}_{1}$. Among the graded fertilizer doses; grade III recorded higher seed cotton and stalk yield than grade I and grade II.

Higher boll weight, seed cotton yield and stalk yield with combined application of organic FYM, and inorganic chemical fertilizer might be due to an extended period of nutrient and moisture availability especially in later stages along with a copious supply of micronutrients and plant growthpromoting substances. These factors altogether have increased the photosynthetic activity and better root zone condition apprehending better yield (Das et al., 2006)

\section{Oil content}

Cottonseed oil content is a nutrient, especially sulphur dependent factor. The $\mathrm{T}_{5}$ recorded highest oil Content $(4.08 \%$ more than the control) although it does not reach the statistical significance level (Table 3).

\section{Effect of nutrient sources on cotton fibre quality}

The fibre quality of the cotton has been evaluated based on the parameters of Upper Half Mean Length -UHML (mm), uniformity 
index (UI\%), fibre fineness based on micronaire- MIC $\left(\mu \mathrm{g} \mathrm{in}^{-1}\right)$, Tenacity $\left(\mathrm{g}\right.$ tex $\left.{ }^{-1}\right)$, Elongation Percentage (\%) and Ginning Percent (\%) (Table 4).

The highest UHML (mm) length has been recorded with $T_{5}$ while $T_{10}$ was statistically at par with it and recorded 3.49\% and 3.06\% longer UHML than the $\mathrm{T}_{1}$. In the case of uniformity index and micronaire value; different treatments do not record any statistically significant result. Tenacity (g tex ${ }^{1}$ ) of the cotton fibre has been influenced due to different treatments and $\mathrm{T}_{5}, \mathrm{~T}_{2}, \mathrm{~T}_{10}, \mathrm{~T}_{11}, \mathrm{~T}_{7}$, $\mathrm{T}_{9}$, and $\mathrm{T}_{4}$ recorded similar results; among these, highest value was recorded with $\mathrm{T}_{5}$ (9.31\% more than $\left.\mathrm{T}_{1}\right)$. The moisture stress often adversely affects the fibre quality; addition of organic FYM helps the plant to evade the moisture stress by storing sufficient moisture at rootzone level (Davidonis et al., 2004). The highest elongation percent was recorded with $\mathrm{T}_{2}$, which was $5.13 \%$ higher than the control, although $\mathrm{T}_{5}, \mathrm{~T}_{9}$, and $\mathrm{T}_{3}$ were at par with $\mathrm{T}_{2}$. Ginning percent was highest in $\mathrm{T}_{11}\left(0.6 \%\right.$ over control) and lowest in $\mathrm{T}_{6}$ (2.03\% less than control). Our result indicates that the nutrient management has a consequent effect on fibre quality; however, sometimes, it is not prominent (Read et al., 2006). The earlier researches suggest that the most prominent factors those directly influences the quality of fibre are $\mathrm{pH}$, SOC and soil phosphorous (Johnson et al., 2002) however we found that even micronutrients have a role to play with fibre quality.

\section{Correlation study}

A correlation study (Table 5) among different yield attributes, yield and quality attributes indicates that strongly positive and moderately positive linear relationship is present among different yield attributes and yield. However, at the same time, these yield attributing factors have moderate to weak positive relationship with quality attributes.
The seed cotton yield and cotton stalk yield are totally positively related to each other. The balanced nutrition helps in significantly better photosynthate movement in the plant, which results in better dry matter accumulation and leaf expansion which in later stages results in better development in fruiting body. An increased number and weight of fruiting body resulted better seed cotton yield. Quality aspects of the fibre, on the other hand, are more of a genetic trait hence does not significantly correlate with quantitative yield attributes.

The result of our experiment concludes that highest yield, oil content and fibre quality of cotton has been observed when recommended dose of fertilizer (60:30:30 kg N, $\mathrm{P}_{2} \mathrm{O}_{5}, \mathrm{~K}_{2} \mathrm{O}$ ) has been conjointly applied with farmyard manure $\left(5\right.$-ton ha $\left.{ }^{-1}\right)$. Addition of sulphur and zinc nutrient with NPK results better than the standalone NPK application but not necessarily better than the combined application of an organic and inorganic source of nutrients.

\section{Acknowledgement}

Authors are thankful to Dr.Panjabrao Deshmukh Krishi Vidyapeeth, Akola for providing financial and research facilities.

\section{Declaration}

Authors declares there is no conflict of interest exist. Further, declare that the manuscript has not been published in any journal/book or proceedings or in any other publication or offered for publication elsewhere in substantially the same or abbreviated form, either in print or electronically.

\section{References}

Abid M, Ahmed N, Qayyum MF, Shaaban M, Rashid A (2013) Residual and 
cumulative effect of fertilizer zinc applied in wheat-cotton production system in an irrigated aridisol. Plant, Soil and Environment 59:505-510.

Ali MA, Ali M, Yar K, Yamin M (2007) Effect of nitrogen and plant population levels on seed cotton yield of newly introduced cotton variety CIM-497. Journal of Agricultural Research (Pakistan).

Anonymous (2016). Area, production and productivity of India and Maharashtra, Directorate of Economics and Statistic Department of Agriculture and $\mathrm{Co}-$ operation, Maharashtra, India.

Blaise D, Majumdar G, Tekale KU (2005a) On-farm evaluation of fertilizer application and conservation tillage on productivity of cotton+ pigeonpea strip intercropping on rainfed Vertisols of central India. Soil and Tillage Research 84:108-117.

Blaise D, Singh JV, Bonde AN, Tekale KU, Mayee CD (2005b) Effects of farmyard manure and fertilizers on yield, fibre quality and nutrient balance of rainfed cotton (Gossypium hirsutum). Bioresource Technology 96:345-349.

Boquet DJ, Moser EB, Breitenbeck GA (1994) Boll weight and within-plant yield distribution in field-grown cotton given different levels of nitrogen. Agronomy Journal 86:20-26.

Chesnin L, Yien CH (1951) Turbidimetric determination of available sulfates 1 . Soil Science Society of America Journal 15:149-151.

Das A, Prasad M, Gautam RC, Shivay YS (2006) Productivity of cotton (Gossypium hirsutum) as influenced by organic and inorganic sources of nitrogen. Indian journal of agricultural science 76:354-357.

Davidonis GH, Johnson AS, Landivar JA, Fernandez CJ (2004) Cotton fiber quality is related to boll location and planting date. Agronomy Journal 96:42-47.

Deshpande AN, Masram RS, Kamble BM (2014) Effect of fertilizer levels on nutrient availability and yield of cotton on Vertisol at Rahuri, District Ahemadnagar, India. Journal of Applied and Natural Science 6:534540.

Follett RH, Murphy LS, Donahue RL (1981) Fertilizers and soil amendments. Prentice-Hall, Inc.

Gokhale DN, Shinde VS, Gadade GD, Sawargaonkar GL, Zade KK (2011) Sustaining rainfed Bt cotton (Gossypium hirsutum L.) productivity through moisture conservation and integrated nutrient management techniques. Journal of Cotton Research and Development 25:197-201.

Gomez KA, Gomez AA (1984) Statistical procedures for agricultural research. John Wiley \& Sons.

Hanway JJ, Heidel H (1952) Soil analysis methods as used in Iowa state college soil testing laboratory. Iowa agriculture $57: 1-31$

Jackson ML, Miller RH, Forkiln RE (1973) Soil chemical analysis Prentic-Hall of India Pvt.\& Ltd. New Delhi: 2nd Indian Rep.

Johnson RM, Downer RG, Bradow JM, Bauer PJ, Sadler EJ (2002) Variability in cotton fiber yield, fiber quality, and soil properties in a southeastern coastal plain. Agronomy Journal 94:13051316.

Katkar RN, Kharche VK, Lakhe SR, Deshmukh PR, Shukla AB, Tivari P, Aage AB, Kadlag, AD (2017) Geographical information system based Micro and Secondary nutrient in soils Maharashtra. Dr. P.D.K.V. Akola. Bulletin No. 491: 10.

Keeney DR, Nelson DW (1982) Nitrogen inorganic forms In Methods of Soil 
Analysis Part II Page, AL et al, Eds American Society of Agronomy. Soil Science Society of America, Madison, WI 643.

Lindsay WL, Norvell WA (1978) Development of a DTPA soil test for zinc, iron, manganese, and copper. Soil science society of America journal 42:421-428.

Mandal DK, Mandal C, Venugopalan MV (2005) Suitability of cotton cultivation in shrink-swell soils in central India. Agricultural Systems 84:55-75.

Marschner H (1995) Mineral nutrition of higher plants. Institute of Plant Nutrition, University of Hohenheim. Academic Press, Harcour Brace, London.

Olsen SR (1954) Estimation of available phosphorus in soils by extraction with sodium bicarbonate. US Department of Agriculture.

Patra DD, Anwar M, Chand S (2000) Integrated nutrient management and waste recycling for restoring soil fertility and productivity in Japanese mint and mustard sequence in Uttar Pradesh, India. Agriculture, ecosystems \& environment 80: 267-275.

Potarzycki J, Grzebisz W (2009) Effect of zinc foliar application on grain yield of maize and its yielding compone. Plant, Soil and Environment 55:519-527.

QingFang Z (1996) Research on the effect of zinc applied to calcareous soil in cotton. China Cottons 23:21.
Read JJ, Reddy KR, Jenkins JN (2006) Yield and fiber quality of upland cotton as influenced by nitrogen and potassium nutrition. European Journal of Agronomy 24:282-290.

Shukla, AK, Tiwari P, Sidhiqqui S, Ashok K. Patra D, and Choudhary SK (2016) Micro and secondary nutrients is Indian soils, condition of deficiency, prevention and recommendations. Indian Institute Soil Science Bhopal., 3: 25.

Singh AL, Joshi YC (2000) Dynamics of sulphur, iron and magnesium and their nutrition in groundnut in calcareous soils of India. Balanced Nutrition of Groundnut and Other Field Crops Grown in Calcareous Soils of India 103.

Subbaiah BV (1956) A rapid procedure for estimation of available nitrogen in soil. Curr Sci 25:259-260.

Swamy U, Wang M, Tripathy JN, Kim S-K, Hirasawa M, Knaff DB, Allen JP (2005) Structure of spinach nitrite reductase: implications for multielectron reactions by the iron- sulfur: Siroheme cofactor. Biochemistry 44:16054-16063.

Venugopalan MV, Pundarikakshudu R (1999) Long-term effect of nutrient management and cropping system on cotton yield and soil fertility in rainfed vertisols. Nutrient cycling in agroecosystems 55:159-164.

\section{How to cite this article:}

Bhagchand Bairwa, R. N. Katkar, Vrushali Bhende, Shrutika Gawande and Subhradip Bhattacharjee. 2020. Influence of Sulphur, Zinc and Organic Inorganic Assorted Customized Fertilizer on Yield and Quality of Cotton under Rainfed Vertisols. Int.J.Curr.Microbiol.App.Sci. 9(08): 3053-3062. doi: https://doi.org/10.20546/ijcmas.2020.908.345 